\title{
Learning Trajectory Siswa dalam Memecahkan Masalah Kelipatan Persekutuan Terkecil Ditinjau dari Kemampuan Matematika
}

\author{
Lydia Lia Prayitno ${ }^{1}$, Agus Prasetyo Kurniawan ${ }^{2}$ \\ ${ }^{1}$ Universitas PGRI Adi Buana Surabaya, Jl. Ngagel Dadi III-B/37 Surabaya \\ ${ }^{2}$ Universitas Islam Negeri Sunan Ampel Surabaya, Jl. A. Yani 117 Surabaya
}

\begin{abstract}
This study aimed to describe students' learning trajectory to solving math problems based on student's ability. The subject is 4th-grade students of Madrasah Ibtidaiyah (MI) K.H. Mas Mansyur Surabaya. The results obtained by learning trajectory are (1) high ability students, expressing the understanding of the problem orally and writing, plan two solutions process, choose to use multiples and sum between departure time and travel time, the subject re-examine every step in solving the problem. (2) medium ability students, expressing an understanding of the problem orally, planning a solution and implementing it until finding a solution, in re-examining the subject using factoring; and (3) low-ability students, expressing an understanding of the problem orally, planning a solution to finding a solution, then simply re-examining the steps taken in solving the problem.
\end{abstract}

Keywords: Learning trajectory; Mathematics problem solving

\section{PENDAHULUAN}

Alur belajar (learning trajectory) menggambarkan urutan pembelajaran (learning sequence) yang harus ditempuh dan konsep-konsep apa saja yang terkait dengan materi yang dipelajari oleh anak, sehingga anak akan dapat belajar dengan tuntas. Bardsley (2006) merumuskan alur belajar pada anak usia pra sekolah dapat digunakan dalam mengajarkan matematika di usia dini. Sedangkan Hadi (2006) merumuskan hipotesis alur belajar untuk materi pecahan di sekolah dasar dan alur belajar pasti terkait dengan desain pembelajaran yang dilakukan di dalam kelas.

Penelitian Chen (2002) menyebutkan dua jenis alur dalam memecahkan masalah matematika yaitu alur belajar, dan alur pemecahan masalah. Alur belajar melukiskan bagaimana proses seorang anak untuk mempelajari sesuatu, sedangkan alur pemecahan masalah yaitu melukiskan langkah-langkah dalam memecahkan sebuah masalah. Alur belajar dalam memecahkan masalah merupakan urutan aktivitas yang dilakukan siswa dalam proses memecahkan masalah dan bergantung pada jenis masalahnya. Jenis masalah matematika terdiri dari dua jenis yaitu problem to find (masalah untuk mencari) dan problem to proof (masalah untuk membuktikan) (Polya, 1973). 
Alur belajar yang dimaksud dalam penelitian ini dipandang sebagai serangkaian aktivitas yang dilakukan siswa dalam memecahkan masalah berdasarkan langkahlangkah Polya. Terdapat empat langkah pemecahan masalah menurut Polya (1973) yaitu (1) memahami masalah, (2) merencanakan penyelesaian; (3) melaksanakan perencanaan; dan (4) melihat kembali hasil yang diperoleh. Hiebert dan Carpenter (1992) mengungkapkan bahwa suatu informasi baik berupa fakta, konsep, atau masalah dapat dipahami jika struktur atau jaringan informasi tersebut merupakan bagian dari struktur atau internal seseorang. Hal ini tentunya melibatkan proses kognitif, yaitu asimilasi dan akomodasi. Dalam proses pemecahan masalah, proses kognitif asimilasi dan akomodasi terjadi terus menerus sampai terjadi equilibrium di kognitif siswa.

Simon mengungkapkan bahwa alur belajar dalam pemecahan masalah terdiri atas tiga komponen utama yaitu: (1) tujuan belajar untuk pembelajaran bermakna, (2) sekumpulan tugas untuk mencapai tujuan-tujuan tersebut, dan (3) hipotesis tentang bagaimana seseorang belajar dan bagaimana seseorang berpikir (Bardsley, 2006). Tujuan belajar yang dimaksudkan dapat berupa memahami konsep atau prinsip dalam matematika. Belajar dibangun melalui tiga komponen utama yaitu tujuan pembelajaran, aktivitas belajar dan proses berpikir, dan hipotesis proses belajar (Blanton, et al., 2015; Bardsley, 2006; Hadi, 2006; Clements \& Sarama, 2004; Chen, 2002).

Soedjadi (2007) memberikan sebuah ilustrasi tentang alur belajar sebagai titik awal dan sebuah tujuan yang ingin dicapai, atau lintasan yang menghubungkan antara awal dan tujuan yang ingin dicapai (disajikan pada Gambar 1). Secara umum, perkembangan kemampuan kognitif seorang anak dimulai dengan hal yang konkrit dan secara bertahap mengarah ke hal yang bersifat abstrak. Bagi setiap anak, lintasan belajar dari hal yang bersifat konkrit menuju abstrak dapat saja berbeda karena ada anak yang cepat dan ada yang lamban sekali. Bagi yang cepat mungkin tidak memerlukan banyak tahapan, tetapi bagi yang lamban sekali tentunya melalui banyak tahapan. Dengan demikian bagi setiap anak mungkin saja memerlukan learning trajectory atau alur belajar yang berbeda, tentunya hal ini akan dipengaruhi lingkungannya. 


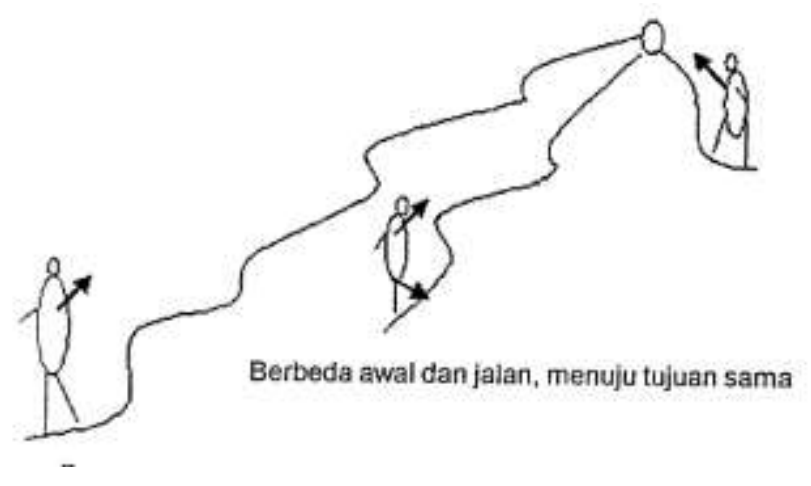

Gambar 1.

Ilustrasi tentang Alur Belajar Anak

Hasil observasi dan wawancara guru pada pra penelitian, didapatkan informasi bahwa siswa masih sering mengalami kesulitan jika dihadapkan pada masalah KPK (Kelipatan Persekutuan terKecil) dan penyelesaiannya. Hal ini sesuai dengan penelitian Musser, Burger, \& Petterson (2011) yang menyatakan bahwa siswa sering kebingungan antara faktor dan kelipatan dimana FPB (Faktor Persekutan terBesar) dan KPK dan sebagai topik yang sulit bagi siswa sekolah dasar. Berdasarkan uraian di atas maka penting untuk mendeksripsikan alur belajar siswa dalam memecahkan masalah matematika pada materi KPK.

\section{METODE PENELITIAN}

Jenis penelitian ini adalah penelitian deskriptif kualitatif yang bertujuan untuk mengkaji alur belajar siswa dalam memecahkan masalah matematika KPK. Data penelitian ini berupa kata-kata. Hal ini sesuai dengan sifat dari penelitian kualitatif (Moleong, 2005). Lokasi dalam penelitian ini adalah Madrasah Ibtidaiyah (MI) KH Abu Mansyur Surabaya. Subjek penelitian terdiri dari tiga siswa kelas IV dengan satu siswa berkemampuan tinggi (S1), satu siswa berkemampuan sedang (S2), dan satu siswa berkemampuan rendah (S3). Penentuan subjek penelitian dilakukan dengan memberikan tes awal. Hal ini bertujuan untuk menentukan kemampuan siswa.

Pengumpulan data dilakukan dengan menggunakan metode tes, wawancara dan think aloud. Penggunaan think aloud bertujuan untuk mengungkap alur belajar subjek. Metode wawancara dilakukan setelah sesi think aloud yang bertujuan untuk menggali informasi bagaimana subjek memahami masalah dan bagaimana subjek memikirkan perencanaan dalam memecahkan masalah. 
Instrumen yang digunakan berupa lembar masalah matematika, pedoman wawancara, handycam untuk merekam aktivitas siswa dalam memecahkan masalah dengan menggunakan think aloud. Data yang diperoleh dari hasil pekerjaan tertulis atau think aloud akan menggambarkan bagaimana subjek melaksanakan perencanaan yang telah dipikirkan dan bagaimana subjek merefleksi hasil yang telah diperolehnya. Hal-hal yang dianggap kurang jelas pada hasil pekerjaan tertulis atau think aloud dapat diperjelas pada wawancara. Hal ini dimaksudkan untuk menggali informasi bagaimana subjek melakukan pemecahan masalah dari setiap langkah Polya tersebut.

Analisis data dilakukan berdasarkan prosedur dan tahapan analisis data dari Moleong (2005) yang terdiri dari enam tahapan yaitu: (1) menelaah seluruh data, (2) reduksi, (3) menyusun dalam satuan-satuan, (4) kategorisasi, (5) koding, dan (6) pemeriksaan data. Analisis data diawali dengan mentranskrip data dari hasil rekaman audio visual. Transkrip data terdiri atas tiga bagian yaitu hasil wawancara, hasil pengucapan pada sesi think aloud dan hasil pekerjaan siswa. Langkah kedua adalah melakukan reduksi data dengan membandingkan data hasil wawancara dengan hasil wawancara dan hasil think aloud. Reduksi data dilakukan dengan membuat rangkuman. Langkah ketiga adalah melakukan pengelompokan data dalam satuan-satuan dengan melakukan pengelompokan sesuai dengan tujuan penelitian. Langkah keempat adalah melakukan kategorisasi data dengan cara mengelompokkan data yang memiliki keterkaitan. Langkah kelima adalah melakukan koding dan langkah terakhir adalah pemeriksaan data.

Pengecekan kredibilitas data dalam penelitian ini dilakukan dengan triangulasi metode yaitu membandingkan data atau informasi dari analisis hasil kerja siswa dengan hasil wawancara yang dilakukan. Triangulasi metode adalah membandingkan dan mengecek balik derajat kepercayaan suatu data atau informasi dengan menggunakan dua metode yang berbeda.

\section{HASIL DAN PEMBAHASAN}

Berikut ini diuraikan hasil penelitian dari masing-masing subjek dengan subjek berkemampuan tinggi (S1), subjek berkemampuan sedang (S2), dan subjek berkemampuan rendah (S3). 


\section{Subjek berkemampuan tinggi (S1)}

Pada tahap memahami masalah, S1 dapat memahami unsur utama dari masalah yang dihadapi. S1 dapat memahami tentang apa yang diketahui, apa yang ditanyakan, apa syarat atau kondisi yang telah ada, serta materi terkait yang dapat dipergunakan untuk menyelesaikan masalah tersebut. Kegiatan yang dilakukan oleh S1 adalah membaca masalah yang diberikan dengan bersuara, mengungkapkan informasi yang mendukung proses penyelesaian masalah. Selanjutnya S1 menuliskan informasi pada lembar jawaban dan dapat menjelaskan secara lisan apa yang diinginkan dalam masalah. S1 juga dapat mengingat kembali masalah serupa yang pernah dijumpai sebelumnya dengan masalah dalam penelitian ini. S1 mengungkapkan bahwa masalah ini dapat diselesaikan menggunakan konsep KPK. Adapun hasil kerja S1 terhadap masalah dapat dilihat pada Gambar 2.

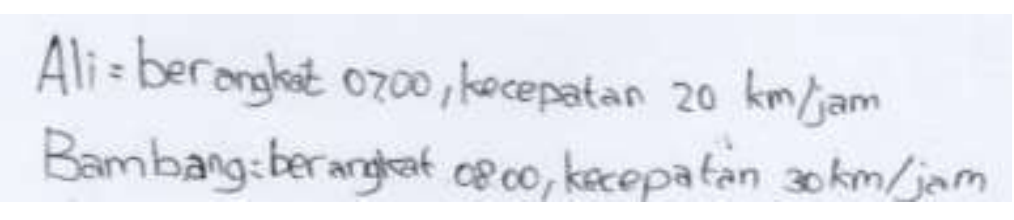

Gambar 2.

S1 Memahami Masalah dengan Menuliskan Informasi Yang Diketahui

Pada tahap merencanakan penyelesaian, S1 menjelaskan bahwa masalah ini dapat diselesaikan menggunakan strategi pemfaktoran dan kelipatan. Pada tahap melaksanakan perencanaan, awalnya S1 memilih menggunakan pemfaktoran. Akan tetapi hasil yang diperoleh tidak seperti yang diinginkan, maka S1 melanjutkan pekerjaannya menggunakan perencanaan kedua yaitu kelipatan. S1 menyelesaikan masalah tersebut menggunakan penjumlahan kemudian menuliskan jawabannya pada lembar jawaban. Hasil jawaban S1 dapat dilihat pada Gambar 3.

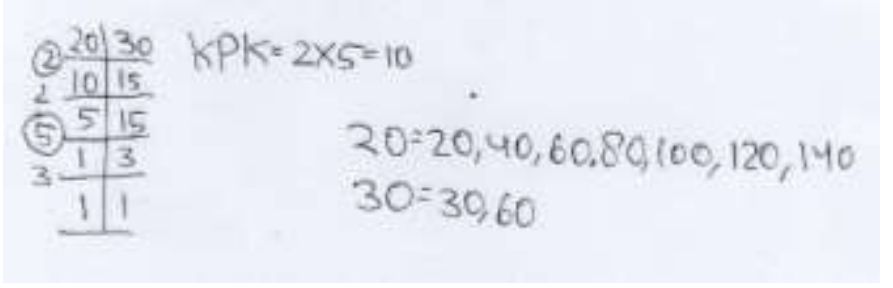

Gambar 3.

S1 Melaksanakan Perencanaan

Setelah menemukan KPK menggunakan kelipatan, S1 menentukan kapan Bambang dapat menyusul Ali. S1 mengungkapkan secara lisan, logika yang digunakan untuk 
memecahkan masalah kemudian menuliskan hasilnya pada lembar jawaban. S1 mengungkapkan bahwa Bambang bisa menyusul Ali jam 10.00 karena Bambang bangun kesiangan, sehingga berangkat jam 08.00 ditambah 2 jam. Hasil jawaban S1 dapat disajikan pada Gambar 4.

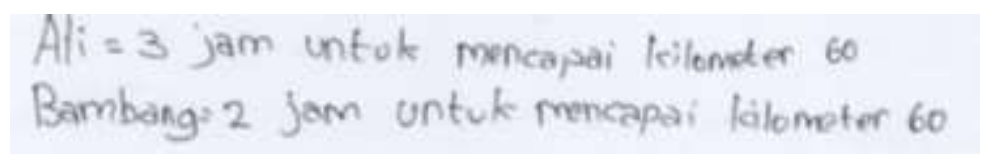

Gambar 4.

S1 Menuliskan Hasil Jawabannya

Pada tahap memeriksa kembali, S1 tidak menggunakan pemfaktoran karena S1 menyadari bahwa hasil yang diperolehnya mengalami kesalahan. S1 memeriksa kembali menggunakan kelipatan dan memeriksa hasil pekerjaannya dari awal sampai pada kesimpulan. Kesimpulan jawaban dari masalah, S1 hanya mengutarakan secara lisan saja bahwa Bambang dapat menyusul Ali pada pukul 10.00 pada kilometer 60 .

Berdasarkan hasil wawancara dengan S1, dapat dikatakan bahwa S1 telah memahami masalah karena dapat mengungkapkan unsur-unsur masalah secara lisan maupun tertulis dengan lengkap. Hiebert \& Carpenter (1992) menjelaskan bahwa memahami ide (konsep), prosedur dan fakta atau masalah matematika merupakan bagian dari struktur atau kerangka jaringan yang telah ada. Struktur masalah dalam penelitian ini merupakan bagian dari struktur yang dimiliki S1.

Awalnya S1 hanya mempunyai satu rencana yaitu pemfaktoran, akan tetapi S1 merubah rencana awal lalu menggunakan rencana kelipatan. S1 mengubah rencana penyelesaian menggunakan kelipatan karena merasa paling dikuasai dan S1 yakin akan jawaban yang diberikan yang diberikan. Sebelum mengubah rencana menggunakan kelipatan, S1 diam beberapa saat dan melanjutkan mengerjakan lembar masalah yang diberikan. Kemudian S1 menyelesaikan masalah dengan menggunakan kelipatan, dan dilanjutkan dengan melakukan penjumlahan antara waktu keberangkatan dengan waktu tempuh yang diperlukan untuk menyusul Ali.

S1 telah memahami ide solusi dengan baik dalam melaksanakan rencana yang telah dibuatnya. Selain itu, S1 juga telah memiliki pengetahuan prasyarat cukup, suatu kebiasaan mental yang baik, serta konsentrasi pada tujuan. S1 juga menyimpulkan hasil akhir yang diperolehnya secara lisan. S1 memeriksa kembali langkah yang dilakukan dalam 
memecahkan masalah, tetapi S1 tidak menggunakan cara pemfaktoran karena telah dicoba dilakukan tetapi hasil yang diperolehnya tidak seperti yang dibayangkan oleh $\mathrm{S} 1$. Untuk memeriksa hasil kerjanya S1 tidak lagi menggunakan think aloud tetapi hanya diam saja sambal mengangguk-anggukan kepalanya. Berdasarkan pengamatan peneliti, S1 telah melaksanakan langkah keempat dari Polya dengan baik, yang dimulai dari memahami masalah, merencanakan penyelesaian, melaksanakan perencanaan dan memeriksa kembali, sehingga secara keseluruhan alur belajar S1 dapat disajikan pada Gambar 5.

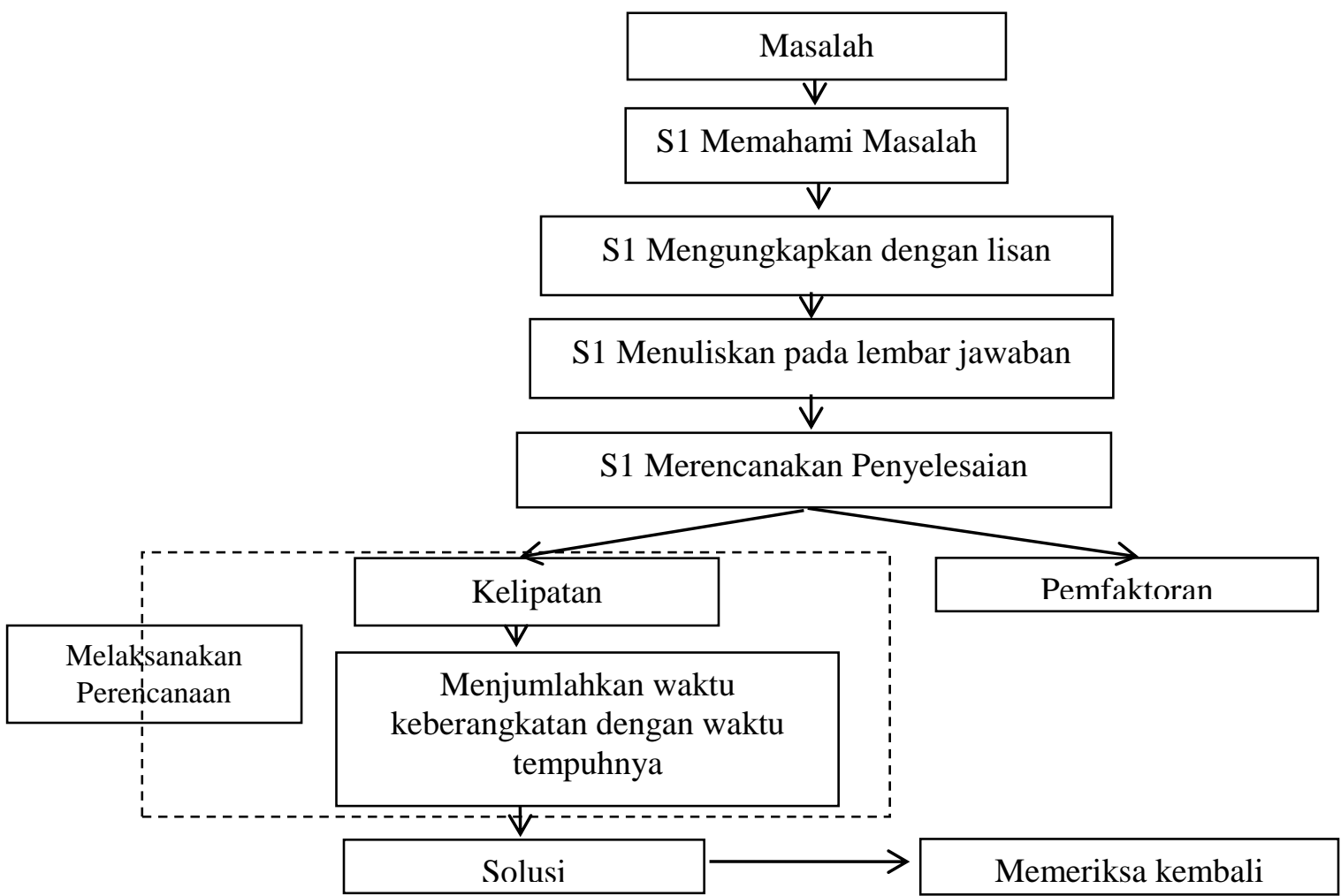

Gambar 5.

Learning Trajectory S1 dalam Memecahkan Masalah

\section{Subjek dengan kemampuan sedang (S2)}

Pada tahap memahami masalah, S2 dapat memahami unsur utama dari masalah yang dihadapi. S2 dapat memahami tentang apa yang diketahui, apa yang ditanyakan, apa syarat atau kondisi yang telah ada, serta materi terkait yang dapat dipergunakan untuk menyelesaikan masalah tersebut. Kegiatan yang dilakukan oleh S2 dalam memahami masalah adalah membaca masalah yang diberikan dengan bersuara. Kemudian mengungkapkan makna dari masalah yang ada dengan bahasanya sendiri, 
dalam hal ini S2 menggambarkan apa yang diketahui dari masalah dan mengungkapkan secara lisan apa ditanyakan dari masalah. Hasil S2 dalam memahami masalah dapat dilihat pada Gambar 6.

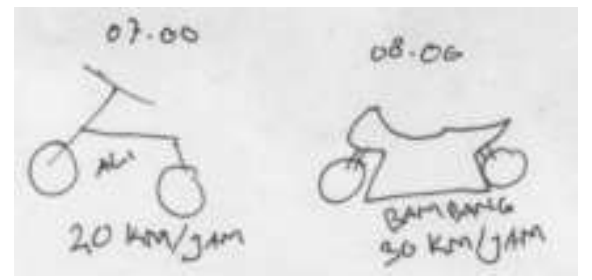

\section{Gambar 6.}

S2 Siswa Memahami Masalah dengan Menggambarkan Masalah

Pada tahap merencanakan penyelesaian, S2 menggunakan kelipatan tetapi S2 mengalami kebingungan untuk mengungkapkan perencanaan yang akan dilakukan. Akan tetapi S2 mampu mengutarakan maksudnya dan diinterpretasikan oleh peneliti melalui pertanyaan pancingan yang dilakukan peneliti.

Pada tahap melaksanakan perencanaan, S2 menyelesaikan masalah yang diberikan menggunakan gambar dan diungkapkan secara lisan. Hal ini seperti dalam kutipan wawancara berikut ini.

$P$ : Coba gimana nyelesaikannya?

S: Kan Ali berangkat jam 7, kecepatan $20 \mathrm{~km} / \mathrm{jam}$, berarti jam 8 Ali sudah sampai di kilometer 20, terus jam 9 sampai di kilometer 40, terus jam 10 sampai di kilometer 60...sek...sek...(dalam bahasa Jawa)

$P$ : Lho kenapa?

S: Sekarang Bambang ya mbak...

Bambang kan berangkatnya jam 8, berarti jam 9 sudah sampai di kilometer 30, terus jam 10 sampai di kilometer 60.

Selanjutnya S2 menyimpulkan jawaban yang diperolehnya bahwa Bambang bisa menyusul Ali jam 10 di kilometer 60. Adapun hasil jawaban S2 dapat dilihat pada Gambar 7.

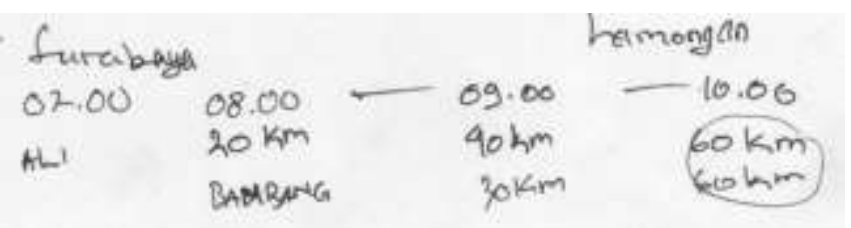

Gambar 7.

S2 Menuliskan Jawaban yang Diperoleh

Pada tahap memeriksa kembali, S2 baru menyadari bahwa untuk menyelesaikan masalah yang diberikan menggunakan KPK. Pada tahap ini, S2 mencoba menggunakan 
pemfaktoran dan menunjukkan bahwa KPK antara 20 dan 30 adalah 60. Berdasarkan jawaban tersebut, S2 menyadari bahwa jawaban yang diberikan sudah benar, sehingga S2 meyakini bahwa Bambang dapat menyusul Ali pada kilometer 60 pada pukul 10.00.

Berdasarkan hasil wawancara, dapat dikatakan bahwa S2 telah memahami masalah karena dapat mengungkapkan unsur-unsur masalah secara lisan dengan lengkap. Hiebert \& Carpenter (1992) menjelaskan bahwa memahami ide (konsep), prosedur dan fakta atau masalah matematika merupakan bagian dari struktur atau kerangka jaringan yang telah ada. Rencana yang digunakan oleh S2 dalam memecahkan masalah yang dihadapi yaitu menggunakan kelipatan. S2 memilih menggunakan kelipatan karena S2 mampu mengerjakan sampai menemukan penyelesaian dari masalah. Pada saat refleksi, S2 baru menyadari bahwa masalah ini dapat diselesaikan menggunakan KPK yang melibatkan pemfaktoran. Dari sini S2 menemukan jawaban yang sama dengan menggunakan kelipatan. S2 telah memahami ide solusi dengan baik dalam melaksanakan rencana yang telah dibuatnya. Selain itu S2 juga telah memiliki pengetahuan prasyarat cukup, kebiasaan mental yang baik, serta konsentrasi pada tujuan, sehingga secara keseluruhan alur belajar S2 dapat disajikan pada Gambar 8.

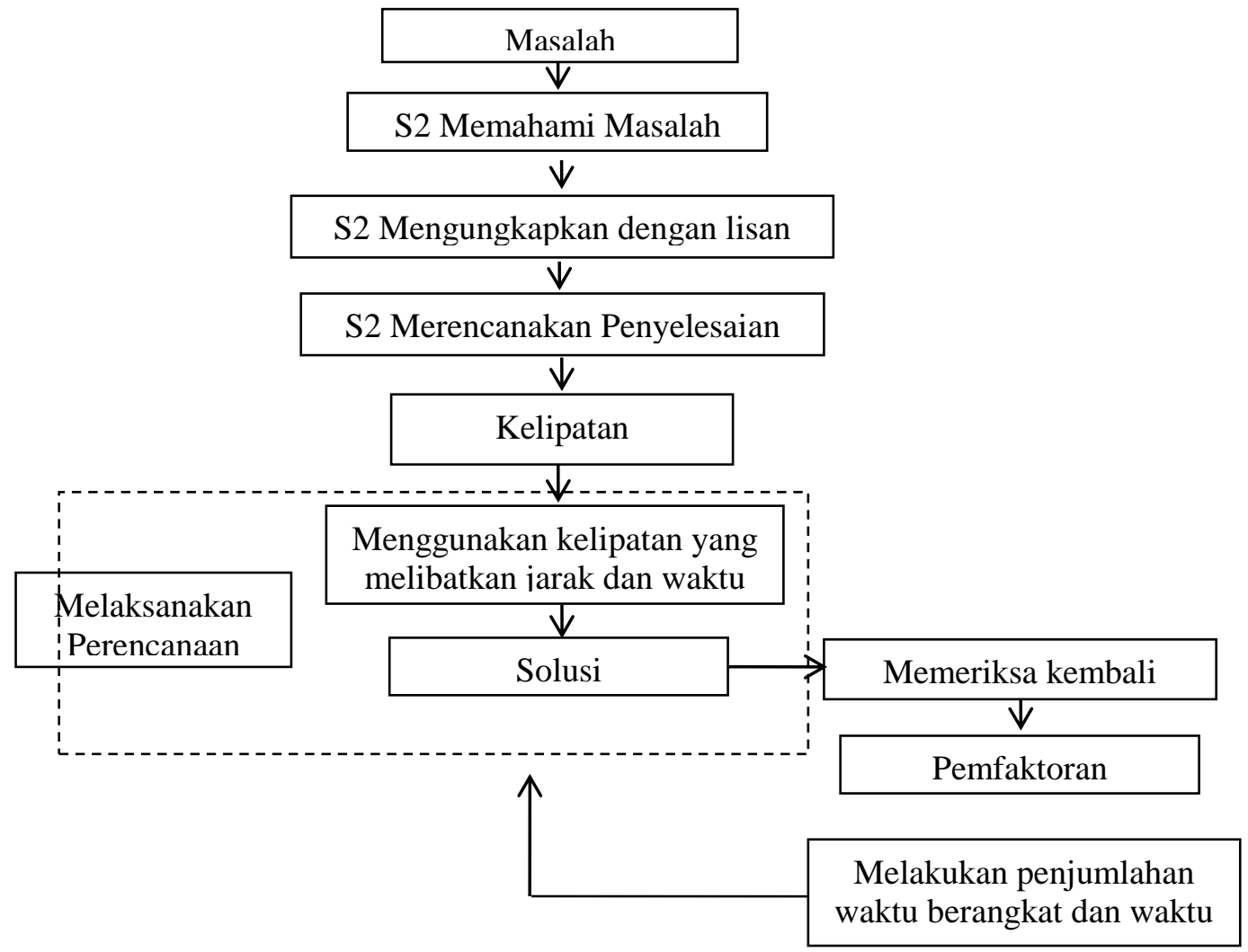

Gambar 8.

Learning trajectory $\mathrm{S} 2$ dalam memecahkan masalah 


\section{Subjek dengan kemampuan rendah (S3)}

Pada tahap memahami masalah, S3 dapat memahami unsur utama dari masalah yang dihadapi. S3 dapat memahami tentang apa yang diketahui, apa yang ditanyakan, apa syarat atau kondisi yang telah ada, serta materi terkait yang dapat dipergunakan untuk menyelesaikan masalah tersebut. Pertama kali S3 membaca masalah yang diberikan dengan bersuara dan menceritakan pemahamannya terhadap masalah yang diberikan.

Pada tahap merencanakan penyelesaian, S3 merencanakan penyelesaian menggunakan kelipatan tetapi S3 juga mengalami kebingungan dalam mengungkapkan perencanaan yang akan dilakukan. S3 mengutarakan maksudnya dalam menyelesaikan masalah ini dan diinterpretasikan oleh peneliti melalui pertanyaan pancingan.

Pada tahap melaksanakan perencanaan, S3 menyelesaikan masalah yang diberikan dengan menggunakan kelipatan yang melibatkan waktu dan jarak tempuhnya. Hasil jawaban S3 dapat dilihat pada Gambar 9.

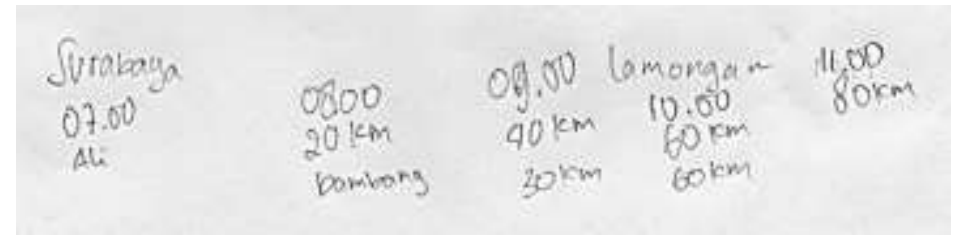

\section{Gambar 9.}

S3 Menuliskan Jawaban yang Diperoleh

Pada tahap memeriksa kembali, S3 tidak mengecek satu persatu setiap langkah jawaban yang memungkinkan terjadi kesalahan. Peneliti juga mencoba menawarkan menggunakan untuk menggunakan cara lain yang ditawarkan oleh S3 tetapi hal ini ditolak oleh S3. Berdasarkan hasil wawancara tersebut terlihat bahwa S3 telah meyakini betul bahwa solusi yang diperoleh sudah tepat dan tidak ingin menggunakan cara yang lain.

Berdasarkan hasil wawancara, dapat dikatakan bahwa S3 telah memahami masalah karena dapat mengungkapkan secara lisan unsur-unsur masalah dengan lengkap, tetapi S3 tidak menuliskannya ke dalam lembar jawaban. Jika ditinjau dari perencanaan yang dilakukan, S3 mempunyai satu rencana untuk memecahkan masalah yang dihadapi, yaitu menggunakan kelipatan dan mampu mengerjakan sampai selesai. S3 menggunakan kelipatan antara waktu dan jarak yang ditempuh Bambang dan Ali. 
Ketika S3 diberikan kesempatan untuk menggunakan cara yang lain, subjek menolaknya. Dalam melaksanakan rencana yang telah dibuatnya, S3 telah memahami ide solusi dengan baik. Selain itu S3 juga telah memiliki pengetahuan prasyarat cukup, kebiasaan mental yang baik, serta konsentrasi pada tujuan. Sehingga secara keseluruhan alur belajar S3 dapat disajikan pada Gambar 10.

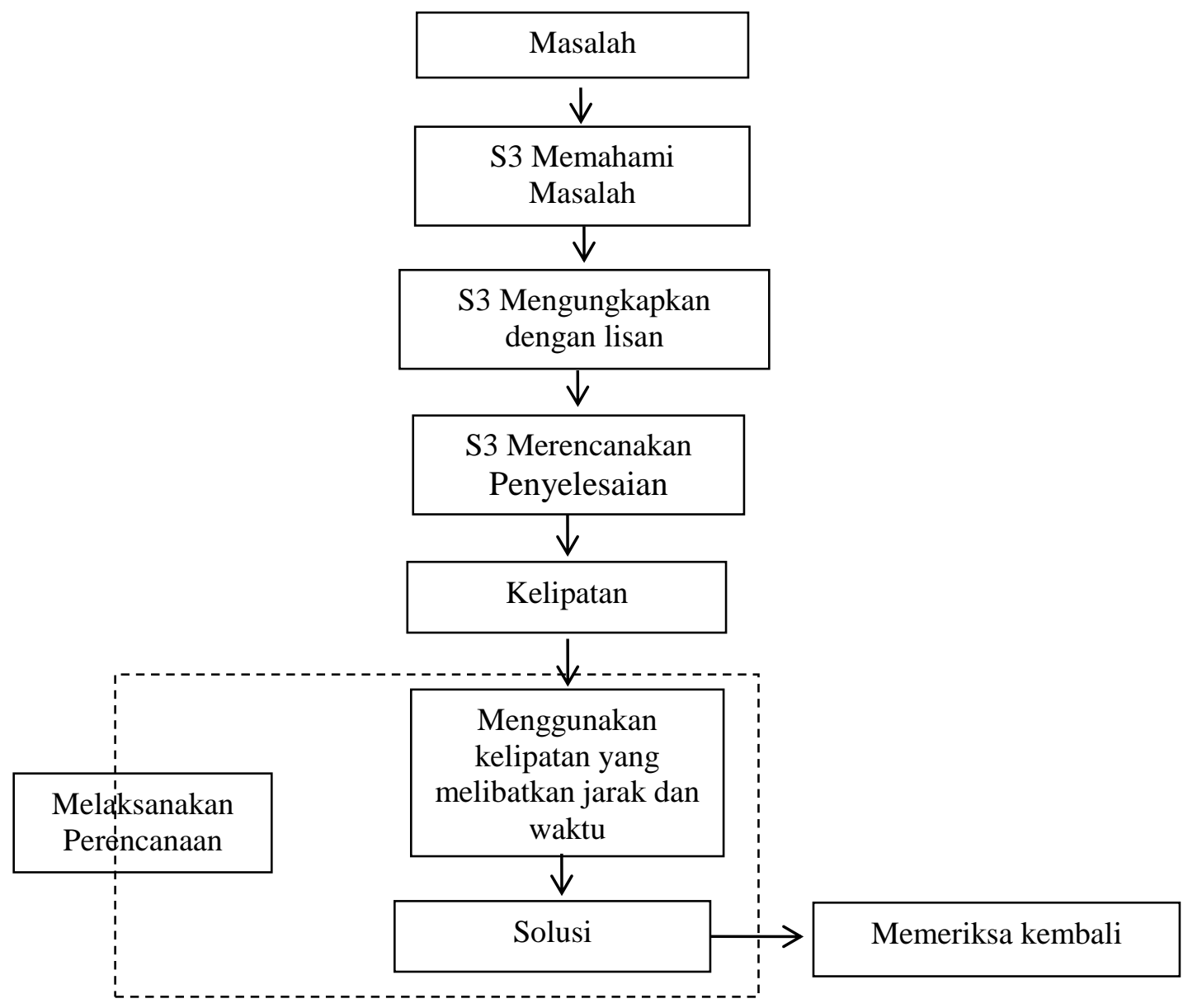

Gambar 10.

Learning Trajectory S3 dalam Memecahkan Masalah

\section{SIMPULAN DAN SARAN}

Learning trajectory S1 dimulai dengan memahami masalah dengan baik. Hal ini dapat dilihat pada kemampuan S1 dalam mengungkapkan komponen masalah dengan benar. Berdasarkan pemahamannya terhadap masalah, S1 memiliki dua perencanaan yang mungkin dilakukan untuk memecahkan masalah tersebut yaitu pemfaktoran dan kelipatan. Awalnya S1 lebih memilih pemfaktoran tetapi S1 beralih menggunakan kelipatan. Selanjutnya, S1 melakukan refleksi dengan kembali menelusuri alur pelaksanaan perencanaan, dengan memeriksa langkah demi langkah. 
Learning trajectory S2 dimulai dengan memahami masalah dengan baik. Hal ini dapat dilihat pada kemampuan S2 dalam mengungkapkan komponen masalah dengan benar. Berdasarkan pemahamannya terhadap masalah, S2 memiliki satu perencanaan yang mungkin dilakukan untuk memecahkan masalah tersebut yaitu kelipatan. Selanjutnya, S2 melakukan refleksi dengan kembali menelusuri alur pelaksanaan perencanaan, dengan memeriksa langkah demi langkah. S2 juga menggunakan pemfaktoran untuk merefleksikan langkah yang dilakukannya sudah tepat. Dari hasil ini S2 memperoleh jawaban yang sama dengan yang diberikan.

Learning trajectory S3 dimulai dengan memahami masalah dengan baik. Hal ini dapat dilihat pada kemampuan S3 dalam mengungkapkan komponen masalah dengan benar. Berdasarkan pemahamannya terhadap masalah, S3 memiliki satu perencanaan yang mungkin dilakukan untuk memecahkan masalah tersebut yaitu kelipatan. Selanjutnya, S3 melakukan refleksi dengan kembali menelusuri alur pelaksanaan perencanaan, dengan memeriksa langkah demi langkah. Tetapi S3 tidak menginginkan menggunakan cara lain untuk merefleksikan jawaban yang diperolehnya. Jadi dapat disimpulkan bahwa learning trajectory S1, S2 dan S3 memberikan konstribusi teori (dalam psikologi kognitif) tentang bagaimana alur belajar siswa dalam pemecahan masalah matematika.

Berdasarkan hasil penelitian maka untuk penelitian selanjutnya agar memperhatikan karakteristik kecerdasan siswa ketika memilih learning trajectory. Selain itu, learning trajectory dapat dikaitkan dengan gaya belajar siswa sehingg bisa dilihat lebih dalam keberhasilan belajarnya.

\section{DAFTAR RUJUKAN}

Bardsley, M. E. (2006). Pre-kindergarten teachers' use and understanding of hypothetical learning trajectories in mathematics education.

Blanton, M., Brizuela, B. M., Gardiner, A. M., Sawrey, K., \& Newman-Owens, A. (2015). A learning trajectory in 6-year-olds' thinking about generalizing functional relationships. Journal for Research in Mathematics Education, 46(5), 511-558.

Chen, C. Y. (2002). A hypothetical learning trajectory of arguing statemants about geometric figures. Diakses 16 November 2016, dari http://www.math.ntnu.edu.tw.

Clements, D. H., \& English, L. D. (2004). Hypothetical learning trajectories (Vol. 6, No. 2). Psychology Press. 
Hadi, S. (2006). Adapting European curriculum material for Indonesian schools. Banjarmasin: Universitas Lambung Mangkurat.

Hiebert, J. \& Carpenter, T. P. (1992). Learning and teaching with understanding. In D. Grouws, (Ed.), Handbook of research on mathematics teaching and learning (pp. 65-97). New York: Mc Millan.

Moleong, J. L. (2005). Metodologi penelitian kualitatif. Bandung: Remaja Rosdakarya.

Musser, G. L., Burger, W. F., \& Petterson, B. E. (2011). Mathematics for elementary teachers: A contemporary approach. USA: John Willey \& Sons Inc.

Polya, G. (1973). How to solve it: A new aspect of mathematical method. Princeton University Press.

Soedjadi, R. (2007). Masalah kontekstual sebagai batu sendi matematika sekolah. Surabaya: PSMS Unesa. 